Review

\title{
Utilization of heterogeneous grasslands by domestic herbivores: Theory to management
}

\author{
Derek W. Bailey ${ }^{a *}$, Bertrand Dumont ${ }^{\mathrm{b}}$, Michiel F. WallisDeVries ${ }^{\mathrm{c}}$ \\ ${ }^{a}$ Northern Agricultural Research Center, Montana State University, \\ Star Route 36, Box 43, Havre, Montana 59501, USA \\ ${ }^{\mathrm{b}}$ Inra, Lab. Adaptation des Herbivores aux Milieux, Centre de Clermont-Ferrand/Theix, \\ 63122 Saint-Genès-Champanelle, France \\ 'De Vlinderstichting-Dutch Butterfly Conservation, Postbus 506, 6700 AM Wageningen, \\ the Netherlands
}

(Received 24 April 1998; accepted 23 July 1998)

\begin{abstract}
Domestic herbivores often utilize heterogeneous grasslands unevenly which can lead to resource degradation. However, uneven grazing can be beneficial for biodiversity. To fulfill multiple land use goals, prediction and management of spatial grazing patterns of livestock are essential. Simulation models based on optimal foraging theory have been useful for quantifying some underlying behavioral mechanisms. Controlled behavioral studies have shown that livestock have cognitive abilities sufficient to solve complex spatial tasks. Livestock appear to evaluate the tradeoffs between travel costs and forage quality and quantity. Recent studies of grazing behavior and spatial movement patterns of livestock have led to development and reevaluation of management tools to modify grazing distribution. Providing water, supplement, salt, shade and shelter can attract livestock to underutilized feeding sites. Selecting animals that are more willing to climb slopes and travel far from water may improve forage use in rugged terrain. To ensure the sustainability and productivity of heterogeneous grasslands, managers must be able to understand and manipulate livestock grazing patterns. Continued research at both theoretical and applied levels is needed. $\odot$ Elsevier/Inra
\end{abstract}

\section{ungulates / grazing / distribution / behavior / biodiversity}

Résumé - Utilisation des pâturages hétérogènes par herbivores domestiques : de la théorie à l'aménagement. Les herbivores domestiques exploitent inégalement les pâturages hétérogènes et peuvent ainsi les dégrader. Cependant, un pâturage inégal favorise la biodiversité. Pour répondre à des objectifs de gestion souvent multiples, il est essentiel de pouvoir prédire et contrôler la distribution spatiale des troupeaux. Des modèles qui utilisent les prédictions de la Théorie de l'Alimentation Optimale ont permis de quantifier certains des mécanismes comportementaux sous-jacents. Des études en situation contrôlée ont montré que les capacités cognitives des herbivores leur permettent

* Correspondence and reprints

Tel.: (1) 4062656115 ; fax: (1) 406265 8288; e-mail: aaxdb@montana.edu 
de tirer parti de l'hétérogénéité des prairies. Les animaux savent aussi évaluer le coût et le probable bénéfice de leurs déplacements. De telles études sur le comportement alimentaire et les règles de déplacement des herbivores permettent d'affiner les recommandations formulées pour aider à la gestion de ces couverts. L'installation de points d'eau, de lieux de supplémentation, de pierres à sel et d'abris permet d'attirer les animaux dans des sites sous-exploités. Sur les terrains accidentés, il est possible de sélectionner les animaux qui acceptent plus volontiers de grimper les pentes et de s'éloigner des points d'eaux. Assurer une exploitation durable de couverts hétérogènes demande de comprendre et savoir modifier les comportements des troupeaux. Cela nécessite un effort continu de recherches tant au niveau théorique qu'en situations concrètes. () Elsevier/Inra

ongulés / pâturage / distribution / comportement / biodiversité

\section{INTRODUCTION}

Domestic herbivores often utilize grasslands unevenly by grazing some areas more than others, which may lead to localized heavy grazing [22]. Uneven grazing distribution can reduce the carrying capacity of grasslands and the efficiency of livestock production $[1,48]$. In the upland areas of Europe, low grazing pressure leads to the creation of unexploited areas that are more and more covered with bracken (Pteridium aquilinum), broom (Cytisus scoparius) and other shrubs. These areas are thus sensitive to running fires, may potentially erode and change aspects of the landscape. In the semiarid US, livestock often congregate along riparian areas [74] where trampling may reduce streambank stability and increase erosion [44]. Concentrated grazing on uplands can reduce litter and vegetative cover which may reduce water infiltration, increase active erosion and increase the sediment load of waterways [77]. On the other hand, uneven grazing distribution leads to heterogeneity that often is beneficial for biodiversity [82]. Since grazing lands are generally managed for multiple goals, optimal land use must consider various, and sometimes conflicting, interests such as maximizing both economical viability and biological diversity [79]. Managers must then consider the spatial variation in grazing to adequately evaluate the impact of grazing by herbivores [22]. Thus, prediction of graz- ing distribution and its management become essential. However, predicting grazing distribution has been difficult [70], and management actions to modify grazing patterns have been limited. Virtually all of the approaches to improve grazing distribution (water development, herding, salting and fencing) were described over 40 years ago [73]. The objectives of this presentation are to explicitly address spatial grazing patterns of livestock and use this information to describe innovative approaches to modify grazing patterns through management.

\section{TEMPORAL AND SPATIAL SCALES}

Temporal and spatial scales must be explicitly described in discussions of foraging patterns of domestic herbivores. In this presentation, we use the temporal and spatial scales defined in Bailey et al. [3]. The smallest spatial scale is a bite. The next larger scale is a feeding station which is defined as an array of plants available to a herbivore without moving its feet [55]. Patches are areas where animals graze before reorienting and moving within a bout. Feeding sites are groups of patches within a contiguous spatial area that animals graze during a foraging bout. Camps are a set of feeding sites that share common foci such as watering or resting sites. Within a pasture there may be one or more camps. A given 
feeding site may be associated with more than one camp. We focus on foraging scales where management has the most impact: camps, feeding sites and patches.

\section{HETEROGENEITY IN GRASSLANDS}

Heterogeneity with respect to grazing distribution can occur in situations where forage species composition is relatively consistent. Patches often form when forage availability is sufficient for livestock to graze selectively $[13,66]$. During the initial forage growth period, domestic herbivores graze in certain areas, and as the vegetation matures animals prefer vegetative regrowth and ignore ungrazed areas. Cattle are more willing to graze reproductive patches than sheep [23]. Correspondingly, grasslands can be simultaneously 'heavily' and 'lightly grazed' as livestock both cause and respond to heterogeneity. Eventually, uneven grazing pattern will result in grazing-intolerant species ('climax') being found in ungrazed patches and grazing-resistant forage species ('seral') in grazed patches [66]. Boundaries of heavily grazed and ungrazed patches fluctuate somewhat, but general locations of the patches remain year after year [86].

Forage species composition affects livestock grazing distribution. Cattle and other domestic herbivores prefer areas with more palatable species $[59,71]$. Factors such as slope and distance to water affect grazing patterns and result in heterogeneity. Domestic herbivores generally avoid steep slopes [53] and avoid traveling long distances from water [78]. These non-forage factors can affect grazing and forage utilization patterns.

\section{FORAGING MECHANISMS}

Domestic and other large herbivores generally allocate the time they spend in an area within a pasture with the resource level found there, usually the standing crop of nutrients or nutrient concentration rather than standing crop of dry matter $[42,59$, 71]. Senft et al. [70] termed this aggregate response pattern as matching. Bailey et al. [3] proposed several mechanisms to explain the matching response pattern. A simple mechanism is that livestock return to nutrient rich areas more frequently than nutrient poor areas [8,9]. A matching pattern could also result from animals traveling more slowly through, and having a higher intake rate in nutrient rich areas $[3,25,35]$.

\subsection{Optimal foraging theory}

Optimal foraging theory (OFT) has been used to explain grazing patterns of herbivores [63]. The patch model is used in OFT to determine where an animal should forage and when the animal should switch between patches [75]. This approach integrates the rewards of staying to feed against the costs of travel to the next patch. It thus offers a quantitative mechanistic basis to explain heterogeneity in forage utilization. Initial tests of the patch model for large herbivores were problematic since handling time, search time and travel time were often indistinguishable and energy was often not the only currency that animals were maximizing $[70,85]$. However, recent work with OFT has been very helpful by explicitly addressing the spatial distribution of patches and evaluating several currencies. Domestic herbivores can be more selective with largescale heterogeneity [84] (WallisDeVries et al., submitted). Apparently, they can better discriminate among alternatives at coarser scales (patches) than finer scales (feeding stations). Computer simulations suggest that travel costs may be an important factor in foraging decisions, even though they constitute less than $10 \%$ of daily energy intake [81]. Thus, the spatial arrangement of patches and feeding sites within the landscape is an important factor affecting livestock grazing patterns [19]. In addition, domestic and wild ungulates may be select- 
ing patches and feeding sites based on multiple resource limitations, i.e., mineral (e.g., sodium and phosphorus) and energy content of forage [14, 85]. Dynamic stochastic programming may provide a technique for addressing the fluctuating nutrient levels typically found on heterogeneous grasslands $[49,54]$.

\subsection{Movements within a grazing bout}

Livestock movement patterns that occur within a grazing bout reflect animal decisions at the feeding station and patch level. Selectivity of cattle and sheep increases with larger scale heterogeneity, and if patches are of sufficient size, they are likely considered a continuous resource [28] (WallisDeVries et al, submitted). Animals move to the nearest patch if they are readily distinguishable and of equal value [35]. More generally, animals appear to evaluate travel distance between patches and edible biomass within patches, and will equally walk to patches with similar food quantities relative to distance [24]. The grazing path of cattle is generally linear with only moderate tortuosity [45] (WallisDeVries et al, submitted). As patches become depleted and intake rate declines, animals will leave the patch [43]. Animals may use visual cues to locate the next patch to forage in. Cattle and sheep can readily associate visual cues with the presence or quality of food, and then use that information in foraging decisions $[30,47$, 64].

The decision of which patch to graze next may be based on several factors. Animals should select patches that maximize longterm energy intake using initial applications of OFT [75]. However, it is difficult to measure long-term energy intake experimentally. Instantaneous energy intake rate does not appear to be a good predictor of longterm energy intake and cattle appear to be maximizing energy on a daily basis [83]. Relying on short-term measurements (e.g., $30 \mathrm{~min}$ ) to determine preferences may lead to erroneous conclusions [23], but there is often some relationship between the predictions made from short and long term relationships [84].

\subsection{Movements between bouts}

As domestic herbivores enter a pasture, they must locate alternative feeding sites. At the beginning of each bout, livestock must decide to stay or move to a new area. In all but small paddocks, livestock cannot use visual and olfactory cues alone to evaluate feeding sites and patches because of distance, vegetative obstructions and topography. Animals acquire information on foraging alternatives from previous experience or exploration [3]. From cross-fostering experiments, Howery et al. [41] found that calves learn where to forage from their dams. Cattle can also learn the locations of feeding sites directly from other animals [5]. Movement patterns of reintroduced Arabian oryx (Oryx leucoryx) suggest that large herbivores expand their habitat by exploring and utilizing previously unused areas [76]. Most OFT patch models assume that animals have knowledge of their habitat such as alternative camps, feeding sites and patches so that they can adequately evaluate marginal intake rates and select patches that maximize long-term energy intake [75]. Cattle and sheep can learn the distribution of food and use that information to forage efficiently $[25,29,46]$. It only took a few 30 -min tests for ewes to learn the location and value of feeding sites where food was densely distributed (figure 1). However, performance was poor when the food distribution was changed after 12 days, which shows that ewes did not locate the food from a distance by smell [25]. Ewes in the smaller parcel learned the new distribution faster than those in a larger parcel (figure 1). Animals can remember the locations of preferred foods more readily when they are aggregated than when locations are dispersed [26].

The location of food can be stored in long-term (reference) memory. Laca [46] 


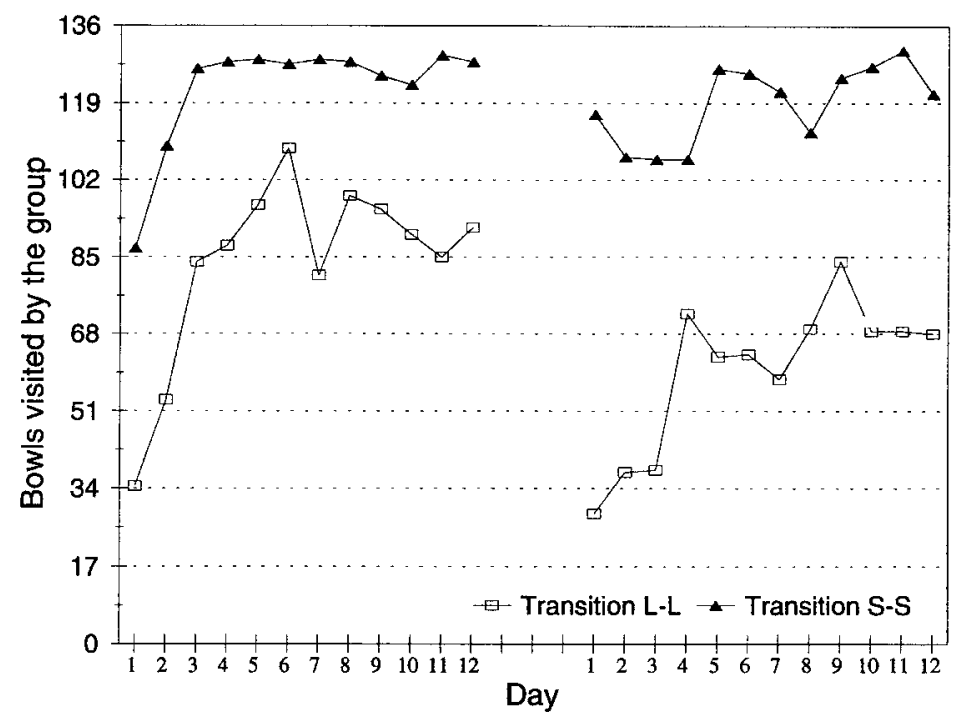

Figure 1. Response of ewes to changing food distribution (after [25]). Number of food bowls visited by groups of three ewes. Food distribution was changed after the first 12-day period. For the $\mathrm{S}-\mathrm{S}$ transition group, the change in food distribution was observed in a smaller parcel $(80 \times 80 \mathrm{~m})$ while the L-L transition group the parcel was larger $(160 \times 160 \mathrm{~m})$.

found that cattle could remember and return to locations where food was found for periods up to 20 days. Domestic herbivores also have accurate short-term (working) memories and can avoid areas where they recently foraged [8]. Quantity and quality of food found at various locations can be stored in memory, and animals will preferentially return to feeding sites with high qualities and/or quantities of food $[9,10]$. Animals learn to avoid areas with lower food quality. However, the association between low food quality and spatial locations may decline over time, and livestock may eventually revisit sites with lower food quality [10].

Day-to-day movement patterns of livestock are difficult and time consuming to observe. In relatively homogeneous grasslands, cattle alternated among feeding areas and rarely grazed the same area for more than two consecutive days $[2,11]$. In a heterogeneous grassland, cattle avoided a feeding area with lower forage quality and alternated among feeding areas with higher forage quality [2]. Individual grazing patterns appear to be relatively consistent from year to year. The home range of cattle on summer mountain range in Idaho was relatively consistent for 2 years [40]. Only $23 \%$ of the cattle shifted their home range significantly. Day-to-day movement patterns of cattle also appear to be relatively stable from year to year. Rank correlations of daily movement patterns collected during the 1996 and 1997 grazing seasons and summarized in transition matrices varied from 0.51 to 0.86 for five cows observed (D.W. Bailey unpublished data). Cows tended to move among feeding sites in same general pattern in both 1996 and 1997.

The observed alternation among desirable feeding sites suggests that animals were searching for areas with greater forage regrowth. The optimal interval between visits to different Cyperus stands was determined to be 4 to 5 days for African buffalo [62]. Domestic herbivores must continually evaluate the trade-off between forage regrowth, forage senescence and competi- 
tion from other herbivores. As the interval between visits increases, the probability of finding forage regrowth increases, however forage will mature during the interval, and the probability of competing herbivores grazing the area increases over time [33].

\section{MANAGING LIVESTOCK GRAZING DISTRIBUTION}

The pattern in which domestic herbivores graze heterogeneous grasslands affects forage defoliation across the landscape. Concentrated heavy grazing in some areas reduces vegetative height standing crop and potentially species composition [86]. Heterogeneity in grazing at low stocking rates creates diversity in vegetation patterns at the landscape scale [60] as well as within grassland communities [13]. This has led to high species diversity in the flora and fauna of traditional semi-natural grazing systems in Europe, where mosaics of short and tall grassland alternate with scrub and wood- land [82]. For example, more species of butterflies are found in landscape types with a greater mosaic of vegetation (figure 2). Overall, $65 \%$ of north-western European butterfly species ( $n=144$ ) depend on mosaic vegetation [15], as microclimate is often crucial and habitat requirements may vary in the course of their life cycle. The majority of butterfly species $(73 \%)$ thrive in grazed areas, particularly when stocking rate is low (53\% of species) [15]. However if livestock grazing is unmanaged and grazing use is excessive, biodiversity can be adversely affected.

The potential benefits of managing grazing distribution are large. Firstly, biodiversity can be managed by modifying livestock grazing patterns [13]. Secondly, changing livestock grazing distribution through management can also alleviate problems associated with localized overgrazing [32]. Land managers often reduce stocking rate in an attempt to correct uneven grazing, but applying management to correct the distribution problem may be more effective [3].

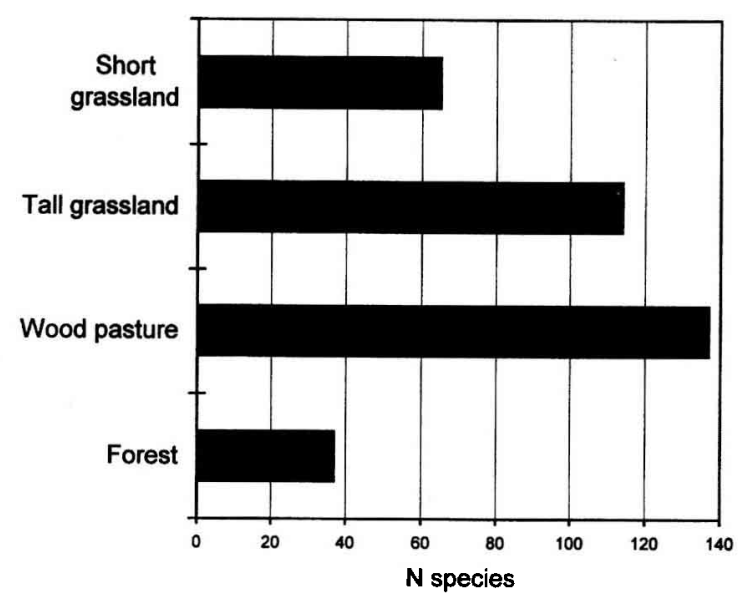

Figure 2. Distribution of northwestern European butterfly species across landscape types (after [15]). Classification of landscape types are based on the predominant vegetation type, but there are inclusions (short grassland landscapes consist of $65-85 \%$ short grassland and include 12-30\% tall grassland and $<5 \%$ woody vegetation; tall grassland landscapes consist of 50-70\% tall grassland with $20-45 \%$ short grassland and $<10 \%$ woody vegetation; wood pasture landscapes consist of $20-60 \%$ woody vegetation and include 5-8\% short grassland and 35-70\% tall grassland; forest landscapes are over $70 \%$ woody vegetation with $<4 \%$ short grassland and $10-25 \%$ tall grassland). 


\subsection{Predicting grazing distribution}

It is difficult to accurately predict the effects of proposed management practices on grazing distribution. We know that developing additional livestock water will improve grazing distribution, but it is difficult to quantify the extent of the improvement. Regression models have been used to predict grazing distribution [20,31, 62], however the models are often site specific [71]. Models based on OFT can be used [81] and have the advantage of building on quantitative mechanisms. Unfortunately, these models are not designed to address management actions [3]. Senft [69] developed a hierarchical model to examine the effect of stocking rate on forage utilization patterns. The conceptual model developed by Bailey et al. [3] has the potential to address management actions on grazing distribution patterns. The model predicts day-to-day movement patterns by integrating travel costs with forage attributes of feeding sites. Each feeding site is rated based on forage quality and quantity as well as the slope, distance to water (horizontal and vertical) and resting sites. Good feeding sites are revisited and poor sites are avoided. It is unique that it incorporates recent work on the cognitive abilities of large herbivores. The model assumes that animals will periodically visit all feeding sites because they forgot their previous rating or because they must update their knowledge for new conditions. The Bailey et al. model [3] is helpful for conceptualizing how various management actions will affect livestock grazing patterns.

\subsection{Make underutilized feeding sites more attractive}

Many management actions designed to improve grazing distribution make certain feeding sites more attractive to livestock (table I). Water, shade and shelter often provide desired resting sites for livestock [72] and make up the central focus area of the camp. If management actions create a new camp or move the focus area of a camp, travel distance to certain areas can be reduced, which may increase the desirability and use of underutilized feeding sites. Providing water in a new location can either move the camp focus area or allow establishment of a new camp. In areas where salt is limiting, strategically placing salt away from water may move the camp slightly because animals periodically use the salting area as a resting site [18]. Cook [21] estimated that carrying capacity could be increased by $13 \%$ through proper salting. Strategic supplement placement may be more effective in moving the camp than salt placement. Roughly, 10 times more cattle were observed in areas where cooked molasses based protein supplements were placed than in control areas [12]. Correspondingly, forage use was nearly 20 times greater in areas with supplement than in control areas. In another study, placing supplement away water reduced heavy grazing on riparian areas from $50 \%$ to $1 \%$ [50]. The same approach was used successfully to encourage sheep to graze heather in a Welsh moorland. Utilization levels up to $20 \%$ were obtained when feed blocks were placed at fixed locations [61]. The central focus area of a camp also can be moved by providing additional shade or shelter away from water and traditional resting sites. In prairies and desert areas with few shrubs or trees, cattle have been lured to underutilized areas by providing posts or other objects that the animal can scratch on (Joe Fallini, personal communication). Developing trails in rugged terrain reduces energetic costs for traveling to remote feeding sites, and thus increases their desirability to grazing livestock.

Improving forage quality can be used to lure cattle to a feeding site. Burning removes standing dead and makes forage more attractive to large herbivores $[17,58]$. Applying nitrogen fertilizer can increase forage utilization from two [27] up to five times [38] the level of unfertilized areas. Use of adja- 
Table I. Summary of relationships between foraging mechanisms and management tools designed to modify livestock grazing distribution.

\begin{tabular}{|c|c|c|}
\hline Goal & Effect on animal & Management practice \\
\hline \multirow[t]{2}{*}{$\begin{array}{l}\text { Increase attractiveness } \\
\text { of underutilized feeding } \\
\text { sites. }\end{array}$} & $\begin{array}{l}\text { Reduce travel costs to } \\
\text { underutilized feeding sites. } \\
\text { Focus of camp may move. }\end{array}$ & $\begin{array}{l}\text { Develop water. } \\
\text { Strategic salt placement. } \\
\text { Strategic supplement placement. } \\
\text { Build trails. } \\
\text { Provide shelter or 'scratch posts'. }\end{array}$ \\
\hline & $\begin{array}{l}\text { Improve forage palatability } \\
\text { at under-utilizcd feeding sites. }\end{array}$ & $\begin{array}{l}\text { Fertilize and improve forage quality. } \\
\text { Burn to remove standing dead forage } \\
\text { and improve forage quality. }\end{array}$ \\
\hline \multirow{2}{*}{$\begin{array}{l}\text { Decrease attractiveness } \\
\text { of overused feeding } \\
\text { sites. }\end{array}$} & Minimize use as resting sites. & $\begin{array}{l}\text { Consistent daily herding away from } \\
\text { sensitive sites. }\end{array}$ \\
\hline & Reduce site desirability. & $\begin{array}{l}\text { Place chemical repellents at sensitive } \\
\text { sites [56]. }\end{array}$ \\
\hline $\begin{array}{l}\text { Prevent preferential } \\
\text { feeding site selection. }\end{array}$ & $\begin{array}{l}\text { Only similar feeding sites } \\
\text { are available. }\end{array}$ & $\begin{array}{l}\text { Avoid enclosing steep and gentle } \\
\text { terrain or lush and dormant forage } \\
\text { in the same pasture. }\end{array}$ \\
\hline \multirow[t]{2}{*}{$\begin{array}{l}\text { Increase animal } \\
\text { preference for rugged } \\
\text { terrain. }\end{array}$} & $\begin{array}{l}\text { Breeding herd is composed } \\
\text { of animals that are more } \\
\text { willing to travel and use } \\
\text { rugged terrain. }\end{array}$ & $\begin{array}{l}\text { Identify and cull animals that } \\
\text { consistently use overgrazed sites. } \\
\text { Select sires from dams that utilize } \\
\text { rough topography. }\end{array}$ \\
\hline & & $\begin{array}{l}\text { Select breeds that use rougher terrain } \\
\text { and areas further from water. }\end{array}$ \\
\hline $\begin{array}{l}\text { Use social interactions } \\
\text { to modify herd } \\
\text { movements. }\end{array}$ & $\begin{array}{l}\text { Herd leaders will be more } \\
\text { likely to travel and use } \\
\text { rugged terrain. }\end{array}$ & $\begin{array}{l}\text { Herd leaders (high social ranking) } \\
\text { with undesirable grazing patterns } \\
\text { should be culled. }\end{array}$ \\
\hline
\end{tabular}

cent unfertilized areas also tends to increase [39]. However, using fertilizer to improve grazing distribution is seldom cost effective and application of fertilizer should be justified on increased forage production [77].

Another approach to increase the use of underutilized feeding areas is to make normally attractive sites such as riparian areas less attractive. In the US, riding and moving cattle to underutilized areas has been recommended for over 40 years [73]. Unfortunately, this practice is often ineffective [65]. Animals often return to preferred sites almost immediately after being herded away. However, consistent daily herding was effective in keeping cattle from riparian areas both in a mountainous area in Idaho [16] and in the Ruby Mountains of Nevada (Jim Maynard, personal communication). In Southern Europe, herding is still a relatively common practice. Shepherds attempt to organize the grazing journey as an ordered sequence of offered feeds. Their objective is to constantly revive the animals' motivation through successive feeding phases having synergetic effects on their appetite. For example, small sainfoin plots strategically used along the grazing journey can increase the intake of coarse resources in oak coppices by more than $20 \%$ [51]. 


\subsection{Changing alternative feeding sites}

Fencing is a direct method for manipulating grazing distribution. Domestic herbivores can be restricted to certain areas, however, grazing distribution within the enclosure can be modified by changing the position of the fence and, correspondingly, the feeding sites and patches enclosed. For uniform grazing distribution, enclosed feeding sites should be as similar as possible [7]. Animals will be less likely to alternate among all feeding sites if areas with divergent vegetation or variable topography are enclosed. In large pastures with diverse feeding sites, livestock should be herded to uplands with developed water rather than lush areas when they first arrive. Thus, livestock's initial evaluation of alternative feeding areas will not include only succulent forage, and animals will be less likely to stay in one area until all the lush forage is consumed [3].

\subsection{Livestock selection}

Selecting livestock based on their grazing patterns has the potential for improving grazing distribution [67]. This suggestion was based on the observations that cattle form social groups that graze in different habitat types. Howery et al. [40] found that cattle showed a high degree of fidelity to a home range indicating the selective culling may change grazing distribution. Differences in grazing patterns have been observed among cattle breeds which also suggests that selection for grazing distribution may be effective. Brangus cattle travel further during grazing than Hereford-Angus cattle [37]. Havstad and Doornbos [36] found differences in distance traveled among cattle with English and Continental breeding but differences were not consistent from year to year. Tarentaise cattle used higher terrain and steeper slopes than Hereford cattle [6]. Meuse-Rhine-Yssel cattle spent more time grazing patches with shorter and less stemmy vegetation, which resulted in a higher quality diet than obtained by Herefords [80]. Salers heifers were more efficient than Limousin heifers having higher biting rates and shorter daily grazing times [57]. Winder et al. [87] suggested that diet selection may be highly heritable. Sire in their Brangus herd accounted for a significant amount of the variation in diet selection for certain forage species during certain times of the year. The corresponding heritability estimates were high $(0.51$ to 0.87 ), but the standard errors for the estimates were also high (0.49 to 0.52 ). Differences in diet selection in the Winder et al.'s [87] study may be the result of variation in spatial grazing patterns. Cattle from some sire groups may have traveled further from water and selected a higher quality diet.

Managers may be able to take advantage of the large variation observed in individual behavior [6] by culling animals with undesirable grazing patterns (e.g., concentrated grazing in bottoms or riparian areas) and selecting animals with desirable grazing patterns (e.g., dispersed grazing of upland slopes). However, determining whether animals have desirable or undesirable behavior is difficult and time consuming, especially because of the diurnal and day-to-day variations in grazing patterns. Readily observable traits are needed to predict individual grazing patterns.

Behavior of cattle during trailing may be related to grazing distribution. Position of animals within the herd during trailing appears to be a reliable, consistent trait. Repeatability of this trait was estimated to be over $60 \%$ for cattle [4]. African buffalo in the middle or back of the herd maintain their general position when grazing or traveling between feeding sites [62]. Cattle found in front of the herd during trailing generally grazed in higher elevations than cattle found in the back of the herd [4]. Other behaviors should be evaluated as predictors of cattle grazing patterns. 
If animals are selected for grazing distribution, managers must consider the effect this selection pressure would have on performance. Grazing distribution was not related to age-adjusted weaning weight of calves, milk production, cow height and cow body condition score [6]. Cows with older calves and correspondingly higher actual weaning weights used higher elevations and steeper slopes than cows with younger calves.

The most important component of a grazing distribution selection program, however, is its effectiveness. To our knowledge no direct tests of this approach have been completed. However, Mosely and Cote [52] suggest that social competition forces subordinate individuals away from preferred areas. Correspondingly, other cows will fill the 'vacuum' if cows grazing preferred areas are removed, and a culling and selection program would be ineffective.

\subsection{Effects of social interactions}

Movements of domestic herbivores during grazing may be directed by a limited number of individual animals. Cattle have been classified as leaders, followers and independents with regards to movement of a social group during grazing [68]. Highranking animals were usually leaders and low ranking members were independent and did not always follow the group. Movement of the herd may be the cumulative result of high-ranking animals and independent movement of low ranking animals. Small herds of cattle generally followed an animal that had special knowledge of locations with highly palatable food [34]. In another study, one or two steers were in the lead when entering a patch and the other two or three steers followed [2]. This suggests that movements and grazing patterns of cattle herds could be changed by selectively culling a few key animals. However, Prins [62] reported from his studies of African buffalo that were no herd leaders and lead animals consistently changed during grazing and while traveling to feeding sites. Data from these studies suggest that the decision where to graze is a communal decision made at the end of a resting bout and before the grazing bout begins. If the results observed in African buffalo are confirmed for domestic livestock, then selectively culling high social ranking animals will have little impact on overall herd movements. The apparent contrast between the studies of cattle and African buffalo may be explained by differences in herd and pasture size. The cattle studies were conducted with small herds where individual animals may have more influence than in large herds of buffalo. In addition, decisions where to graze may be more distinct in large acreages than in the small pastures used for these cattle studies since animals often travel further before actively grazing. Obviously, more research is needed to evaluate the impacts of social interactions on herd movement patterns during grazing.

\section{CONCLUSIONS}

Multiple, and often conflicting, management goals for heterogeneous grasslands have caused managers and researchers to place new emphasis on livestock grazing distribution. Heterogeneity can result from differences in botanical composition, forage utilization or vegetative height, topography or distance to water. Livestock have accurate spatial memories and appear to have sufficient cognitive abilities to select patches and feeding sites based on travel costs and the quality and quantity of forage expected to be there. Controlled behavioral studies have provided new insights in the cognitive abilities of livestock and are providing a framework for developing models to predict grazing patterns. Predictive models are needed to quantify the effects of management practices on livestock grazing distribution patterns. Additional emphasis should be placed on developing and evalu- 
ating models that can predict grazing movements and forage utilization patterns of livestock on heterogeneous grasslands and rangelands.

Interest in spatial grazing patterns of ungulates, and especially livestock, have resulted in both controlled and field scale grazing behavior studies. This work has prompted development of new approaches to improve livestock grazing distribution. With continued scientific interest in the spatial movements of domestic herbivores, managers should have more tools to manage animals in a manner that ensures the sustainability and improvement of heterogeneous grasslands.

\section{REFERENCES}

[1] Anderson E.W., Grazing systems as methods of managing the range resources, $J$. Range Manage. 20 (1967) 383-388.

[2] Bailey D.W., Daily selection of feeding areas by cattle in homogeneous and heterogeneous environments, Appl. Anim. Behav. Sci. 45 (1995) 183-199.

[3] Bailey D.W., Gross J.E., Laca E.A., Rittenhouse L.R., Coughenour M.B., Swift D.M., Sims P.L., Mechanisms that result in large herbivore grazing distribution patterns, J. Range Manage. 49 (1996) 386-400.

[4] Bailey D.W., Hoffman M., Position of cattle within the herd during a trai] drive, Abstr., 51 st Ann. Mtg. Soc. Range Manage. (1998) p. 16.

[5] Bailey D.W., Howery L.D., Boss D.L., The influence of social facilitation for locating feeding sites in cattle, Abstr., 51 st Ann. Mtg. Soc. Range Manage. (1998) 16.

[6] Bailey D.W., Kress D.D., Anderson D.C., Boss D.L., Davis K.C., Relationship between grazing distribution patterns and performance of beef cows, Abstr. 90th Ann. Mtg. Amer. Soc. Anim. Sci. (1998).

[7] Bailey D.W., Rittenhouse L.R., Management of cattle distribution, Rangelands 11 (1989) 159-161.

[8] Bailey D.W., Rittenhouse L.R., Hart R.H., Richards R.W., Characteristics of spatial memory in cattle, Appl. Anim. Behav, Sci. 23 (1989) $331-340$.

[9] Bailey D.W., Rittenhouse L.R., Hart R.H., Swift D.M., Richards R.W., Association of relative food availabilities and locations by cattle, J. Range Manage. 42 (1989) 480-482.
[10] Bailey D.W., Sims P.L., Association of food quality and locations by cattle, J. Range Manage. 51 (1998) 2-8.

[11] Bailey D.W., Walker J.W., Rittenhouse L.R., Sequential analysis of cattle location: day-today movement patterns, Appl. Anim. Behav. Sci. 25 (1990) 137-138.

[12] Bailey D.W., Welling G.A., Modifying livestock grazing distribution by strategic placement of cooked molasses supplements, Abstr. 90th Ann. Mtg. Amer. Soc. Anim. Sci. (1998).

[13] Bakker J.P., Nature Management by Grazing and Cutting, Kluwer, Dordrecht, 1989.

[14] Belovsky G.E., Diet optimization in a generalist herbivore: the moose, Theor. Pop. Biol. 14 (1978) 105-134.

[15] Bink F., Ecologische Atlas van de Dagvlinders van Noordwest-Europa, Schuyt \& Co., Haarlem, 1992.

[16] Butler P., Herding cows like sheep on the National Forest using a Peruvian herder, Abstr., 5 lst Ann. Mtg. Soc. Range Manage. (1998) 23.

[17] Canon S.K., Urness P.J., DeByle N.V., Habitat selection, foraging behavior, and dietary nutrition of elk in burned aspen forest, J. Range Manage. 40 (1987) 433-438.

[18] Cassini M.H., Hermitte G., Patterns of environmental use by cattle and consumption of food blocks. Appl. Anim. Behav. Sci. 32 (1992) 297-312.

[19] Clarke J.L., Welch D., Gordon I.J., The influence of vegetation pattern on the grazing of heather moorland by red deer and sheep. I. The location of animals on grass/heather mosaics, J. Appl. Ecol. 32 (1995) 166-176.

[20] Cook C.W., Factors affecting utilization of mountain slopes by cattle, J. Range Manage. 19 (1966) 200-204.

[21] Cook C.W., Increased capacity through better distribution on mountain ranges, Utah Farm Home Sci. 28 (1967) 39-42.

[22] Coughenour M.B., Spatial components of plantherbivore interactions in pastoral, ranching and native ungulate ecosystems, J. Range Manage. 44 (1991) 530-542.

[23] Dumont B., D’hour P., Petit M., The usefulness of grazing tests for studying the ability of sheep and cattle to exploit reproductive patches of pastures, Appl. Anim. Behav. Sci. 45 (1995) 79-88.

[24] Dumont B., Dutronc A., Petit M., How readily will sheep walk for a preferred forage?, J. Anim. Sci. 76 (1998) 965-971.

[25] Dumont B., Petit M., Spatial memory of sheep at pasture, Appl. Anim. Behav. Sci. 60 (1998) 43-53.

[26] Dumont B., Pouillon A., D' hour P., Can patch distribution affect diet selection by sheep?, Ann. Zootech. 47 (1998) 506. 
[27] Duncan A.J., Hartley S.E., Iason G.R., Finescale discrimination of forage quality by sheep offered a soyabean meal or barley supplement while grazing a nitrogen-fertilized heather ( $\mathrm{Cal}$ luna vulgaris) mosaic, J. Agric. Sci. (Camb.) 123 (1994) 363-370.

[28] Edwards G.R., Newman J.A., Parsons A.J., Krebs J.R., Effects of scale and spatial distribution of the food resource and animal state on diet selection: an example with sheep, J. Anim. Ecol. 63 (1994) 816-826.

[29] Edwards G.R., Newman J.A., Parsons A.J., Krebs J.R., Use of spatial memory by grazing animals to locate food patches in spatially heterogeneous environments: an example with sheep, Appl. Anim. Behav. Sci. 50 (1996) 147-160.

[30] Edwards G.R., Newman J.A., Parsons A.J., Krebs J.R., Use of cues by grazing animals to locate food patches: an example with sheep, Appl. Anim. Behav. Sci. 51 (1997) 59-68.

[31] Gillen R.L., Krueger W.C., Miller R.F., Cattle distribution on mountain rangeland in northeastern Oregon, J. Range Manage. 37 (1984) 549-553.

[32] Gordon I.J., Dennis P., Multiple-scale impacts of large herbivore grazing and biodiversity management in the uplands, in: Simpson I.A., Dennis P. (Eds.), Spatial Dynamics of Biodiversity. Towards and Understanding of Spatial Patterns and Processes in the Landscape, The UK Region of the International Association for Landscape Ecology, University of Stirling, pp. 25-32.

[33] Gordon 1.J., Lindsay W.K., Could mammalian herbivores 'manage' their resource?, Oikos 57 (1990) 270-280.

[34] Greenwood P.T., Rittenhouse L.R., Feeding area selection: the leader-follower phenomenon, in: Proc. West. Sec. Amer. Soc. Anim. Sci. 48 (1997) 267-269.

[35] Gross J.E., Zank C., Hobbs N.T., Spalinger D.E., Movement rules for herbivores in spatially heterogeneous environments: responses to small scale pattern, Landscape Ecol. 10 (1995) 209-217.

[36] Havstad K.M., Doornbos D.E., Effect of biological type on grazing behavior and energy intake, Proceedings of the Grazing Livestock Nutrition Conference, Jackson, Wyoming, 1987, pp. 9-15.

[37] Herbel C.H., Nelson A.B., Activities of Hereford and Santa Gertrudis cattle on a southern New Mexico range, J. Range Manage. 19 (1966) 173-181.

[38] Holt G.A., Wilson D.G., Effect of commercial fertilization of forage production and utilization a desert range site. J. Range Manage. 14 (1961) 252-256.

[39] Hooper J.F., Workman J.P., Grumbles J.B., Cook C.W.. Improved livestock distribution with fertilizer. A preliminary economic cvaluation, J. Range Manage. 22 (1969) 108-1 10.
[40] Howery L.D., Provenza F.D., Banner R.E., Scott C.B., Differences in home range and habitat use among individuals in a cattle herd, Appl. Anim. Behav. Sci. 49 ( 1996) 305-320.

[41] Howery L.D., Provenza F.D., Banner R.E., Scott C.B., Social and environmental factors influence cattle distribution, Appl. Anim. Behav. Sci. 55 (1998) 231-244.

[42] Hunter R.F., Hill sheep and their pasture: a study of sheep-grazing in south-cast Scotland, J. Ecol. 50 (1962) 651-680.

[43] Jiang Z., Hudson R.J., Optimal grazing of wapiti (Cervus elaphus) on grassland: patch and feeding station departure rules. Evol. Ecol. 7 (1993) $488-498$.

[44] Kauffman J.B., Krueger W.C., Vavra M., Impacts of cattle grazing streambanks in northeastern Oregon, J. Range Manage. 36 (1983) 683-685.

[45] Keil M.R., Rittenhouse L.R., Swift D.M., Whittier J.C., Environmental patterns-cattle interactions along the grazing pathway, Abstr. 51st Ann. Mtg. Soc. Range Manage. (1998) 22.

[46] Laca E.A., Spatial memory and food searching mechanisms of cattle, J. Range Manage. 51 (1998) 370-378.

147] Laca E.A., Ortega I.M., Integrating foraging mechanisms across spatial and temporal scales, in: West N.E. (Ed.), Proceedings of the Fifth International Rangeland Congress, Society for Range Manage., Denver, Colorado, 1996, pp. $129-132$.

1481 Loiseau P., Martin-Rosset W., Évolution à long terme d'une lande de montagne pâturée par des bovins ou des chevaux, Agronomie 9 (1989) 161-169

[49] Mangel M., Clark C.W., Dynamic Modeling in Behavioral Ecology, Princeton Univ. Press, Princeton, New Jersey, 1986.

[50] McDougald N.K., Frost W.E., Jones D.E., Use of supplemental feeding locations to manage cattle use on riparian areas of hardwood rangelands, in: Proceedings California Riparian Systems Conference, Davis, California, 1988. USDA Forest Service Gen. Tech. Rep. PSW-110, 1988, pp. 124-126.

[51] Meuret M., How do I cope with that bush? Optimizing less palatable feeds at pasture using the MENU model, in: Lindberg J.E. et al. (Eds.), Recent Advances in Small Ruminant Nutrition, Options Méditerranéennes A34, 1997, pp. 53-57.

[52] Mosely J., Cote N., Do some cows prefer to graze uplands rather than riparian areas, Proc. Governor's Conference on the Cattle Industry, Great Falls, Montana, 1997, pp. 147-148.

[53] Mueggler W.F., Cattle distribution on steep slopes, J. Range Manage. 18 (1965) 255-257.

[54] Newman J.A., Parsons A.J., Thornley J.H.M., Penning P.D., Krebs J.R., Optimal diet selection by a generalist grazing herbivore. Funct. Ecol. 9 ( 1995 ) 255-268. 
[55] Novellie P.A., Comparison of the foraging strategies of blesbok and springbok on the Transvalal highveld, South African J. Wildl. Res. 9 (1978) $137-144$

[56] Osoko T.J., Hardin R.T., Young B.A., Chemical repellants to reduce grazing intensity on reclaimed sites, J. Range Manage. 46 (1993) $383-386$

[57] Petit M., Garel J.P., D'hour P., Agabriel J., The use of forages by the beef cow herd. in: Journet M. et al. (Eds.), Recent Developments in the Nutrition of Herbivores, Proceedings of the 4th International Symposium on the Nutrition of Herbivores, Inra Editions, Paris, 1995. pp. 473-496.

[58] Pfeiffer K.E., Hartnett D.C., Bison selectivity and grazing response of little bluestem in tallgrass prairie, J. Range Manage. 48 (1995) 26-31.

[59] Pinchak W.E., Smith M.A., Hart R.H., Waggoner J.W. Jr., Beef cattle distribution patterns on foothills range, J. Range Manage. 44 (1991) 267-275.

[60] Pott R., Effects of human interference on the landscape with special reference to the role of grazing livestock, in: WallisDeVries M.F. Bakker J.P., Van Wieren S.E. (Eds.). Grazing and Conservation Management, Kluwer Academic Publ., London, 1998, in press.

[61] Powell T.L., Modifying ranging behaviour of sheep on mountain grazings with feed blocks, British Grassland Society 5th Research Conference, University of Plymouth, 8-10 September, 1997.

[62] Prins H.H.T., Ecology and Behaviour of the African Buffalo - Social Inequality and Decision Making, Chapman Hall, London, 1996.

[63] Pyke G.H., Optimal foraging theory: a critical review, Annu. Rev. Ecol. 15 (1984) 523-575.

164] Renken W.J., Howery L.D., Ruyle G.B., Location of feed rewards by beef heifers based on the presence of visual cues, Abstr., 51 st Ann. Mtg. Soc. Range Manage. 1998.

[65] Rhodes B.J., Marlow C.B., Intensive range riding for improving livestock distribution, Abstr. $50^{\text {th }}$ Ann. Mtg. Soc. Range Manage., 1997. pp. $38-39$

[66] Ring C.B. II, Nicholson R.A., Lanchbaugh J.L., Vegetational traits of patch-grazed rangeland in west-central Kansas, J. Range Manage. 38 (1985) 5l-55.

[67] Roath L.R., Krueger W.C., Cattle grazing and behavior on a forested range, J. Range Manage. 35 (1982) 332-338.

[68] Sato S., Leadership during actual grazing in a small herd of cattle, Appl. Anim. Ethol. 8 (1982) 53-65.

[69] Senft R.L., Hierarchical foraging models: effects of stocking and landscape composition on simulated resource use by cattle, Ecol. Model. 46 (1989) 283-303.

[70] Senft R.L., Coughenour M.B., Bailey D.W., Rittenhouse L.R., Sala O.E., Swift D.M., Large herbivore foraging and ecological hierarchies, BioScience 37 (1987) 789-799.

[71] Senft R.L., Rittenhouse L.R., Woodmansee R.G., Factors influencing patterns of cattle behavior on shortgrass steppe, J. Range Manage. 38 (1985) $82-87$.

[72] Senft R.L., Rittenhouse L.R, Woodmansee R.G., Factors influencing selection of resting sites by cattle on shortgrass steppe, J. Range Manage. 38 (1985) 295-299.

[73] Sklovin J.M., Range riding - the key to range management, J. Range Manage. 10 (1957) 269-27l.

[74] Smith M.A., Rodgers J.D., Dodd J.L., Skinner Q.D., Declining forage availability effects on utilization and community selection by cattle, J. Range Manage. 45 (1992) 391-395.

[75] Stephens D.W., Krebs J.R., Foraging Theory, Princeton Univ. Press, Princeton, 1996.

[76] Tear T.H., Mosley J.C., Ables E.D., Landscapescale foraging decisions by reintroduced Arabian oryx, J. Wildl. Manage. 61(1997) 1 l42-1 I54

[77] Vallentine J.F., Grazing management, Academic Press, San Diego, California, 1990.

[78] Valentine K.A., Distance from water as a factor in grazing capacity of rangeland, J. Forest. 45 (1947) 749-754.

[79] Vavra M., Livestock and big game relationships, Rangelands 14 (1992) 57-59.

[80] WallisDeVries M.F., Foraging in a landscape mosaic - diet selection and performance of freeranging cattle in heathland and riverine grassland, Ph.D. thesis, Agricultural University Wageningen, the Netherlands, 1994, 161 p.

[81] WallisDeVries M.F., Effects of resource distribution patterns of ungulate foraging behaviour: a modelling approach, Forest Ecol. Manage. 88 (1996) 167-177.

[82] WallisDeVries M.F., Bakker J.P., Van Wieren S.E. (Eds.) Grazing and Conservation Management. Kluwer Academic Pub1., London, 1998, in press.

[83] WallisDeVries M.F., Daleboudt C., Foraging strategy of cattle in patchy grassland, Oecologia 100 (1994) 98-106.

[84] WallisDeVries M.F., Laca E.A., Demment, M.W., From feeding station to patch: scaling up food intake measurements in grazing cattle, Appl. Anim. Behav. Sci. (1998) 301-305.

[85] WallisDeVries M.F., Schippers P., Foraging in a landscape mosaic: selection for energy and minerals in free-ranging cattle, Oecologia 100 (1994) 107-117.

[86] Willms W.D., Dormaar J.F., Schaalje G.B., Stability of grazed patches on rough fescue grasslands, J. Range Manage. 41 (1988) 503-508.

[87] Winder J.A., Walker D.A., Bailey C.C. Genetic aspects of diet selection in the Chihuahuan desert, J. Range Manage. 48 (1995) 549-553. 